\title{
RACISM IN GERMANY AND ITS IMPACT ON THE TURKISH MINORITY
}

FARUK ŞEN

Europe is facing a confrontation presently. On one hand, the protection of human rights has gained weight in public discussion and political negotiation. On the other hand, aggressive nationalism, racism and xenophobia are gaining ground. Therefore, one of the most challenging issues of the future Europe will be, and already is, migration. Increasinly migration has been linked to the concepts of democracy and human rights while efforts are being made to arrive at a European Union, with its deficiencies with regard to the rights of migrants. The two are linked because how migrants and foreign populations are incorporated into the social and political life of the receiving countries is a major cxplanatory element of the understanding of democracy, pluralism and human rights in Europe.

I will start by reviewing the situation of the Turks in Europe and particulary in Germany. The Turkish population living in Western Europe is about 2.7 million. This makes up, not only the largest minority group living in the EU countries, but it also means that approximately $4 \%$ of the population of Turkey lives in Europe. The number of Turkish citizens living in the European Union today is about half of the population of Denmark, six times that of Luxembourg, two-thirds that of Ireland and onc-fourth of the populations of Greece and Portugal.

Looking at the former Federal Republic of Germany, there are about 6,878 million foreigners living in Germany as end of 1993. Three-fourths of them have come from the Mediterranean countries. The largest group among them is the Turks with a population of 1,918 million, followed by migrants from the former Yugoslavia, Italians, Greeks, Spanish, Portugeuse, Moroccans and Tunisians. Turks make up $2.36 \%$ of the total population of Germany, which is about 81 million. 
Today although not officially acknowledged, many European countries have become countries of immigrants. Worldwide economic and social disparities cause migratory flows to Europe from other parts of the world and as long as these disparities are not eliminated, it will not be possible to prevent such flows totally. It is very important to determine how to control and manage migration flows to and within Europe in a humane way and how to achicve an acceptable level of immigration.

Promotion of human rights, population and health programmes, protection of the environment, promotion of human resource development and job creation are necessary to reduce migration pressures. Governments of countries of origin and destination should seck to reduce the causes of migration by actions such as above, which will not only require financial assistance, but also an adjustment of the commercial, tariff and financial relations in order to revitalize the economies of the countries of origin.

Even though migration from Turkey to Western Europe might continue at a relatively slow pace through family reunifications and formations, it is evident that the majority of the Turkish population in Europe intends to stay permanenty in Europe. For instance, about half of the migrants have a more than ten years residence in Germany. More than twothirds of the Turkish children and youth are bom in Germany.

The Turkish population in Germany is characterized as a very hetcrogeneous group. For instance, only 33\% pursues an occupation in the status of a salaried worker, while the remaining two-third is composed of spouses, children and family members. The recent racist attacks in Germany has caused some Turks to consider the option of returning to Turkey. Yet, this is no longer a feasible option for the significant proportion of Turks who look upon Germany as a country of settlement. According to the findings of the Center for Studies on Turkey, $83 \%$ of the Turks in the Federal Republic of Germany do not consider returning to Turkey.

Until today $34,6 \%$ of Turks in Germany have secured a savings contract with German buildings societies. More than 45.000 Turks have acquired real estate in the Federal Republic of Germany. This number is expected to double until the year 2000. Presently there are more than 135.000 Turks who have enclosed a saving contract with a building society.

In $1973,89 \%$ of the Turks living in Germany were men, and $91 \%$ were employed as workers with social security. However, coming to 1993, we sce that only $29 \%$ of the Turks in Germany are employed as workers with social security. The rest consists of dependent family members, and some 37.000 self-employed businessmen. 
It should also be mentioned that especially among the 14.700 Turkish university students in Germany, the desire to establish one's own business is very high. This results partly from the widely shared belief among the Turkish students that their employment opportunities after graduation are not very promising. Apart from the 14.500 Turkish students in the universities, some 450.000 Turkish children are registered in the German education system from elementary education level to high school.

\section{Preventing Xenophobia and Racism:}

As stated above, Europe is faced with a confrontation today. Although human rights have become significant in all political discussions and negotiations, we see an increasing trend of aggressive nationalism, growing racism and xenophobia in Europe. There are the efforts of international bodies such as the CSCE, Council of Europe, the ILO and the United Nations through conventions concerning the legal status of migrant workers and on the elimination of all forms of racial discrimination, but yet the establishment of a European Union led to the creation of a "European fortress" in order to set up a defence apparatus against mass immigration from less developed countries.

Despite the restrictions of entry into the western European countries, reality moves in a different direction. First of all, classical labour migration continues in the form of selective recruitment for special professions on a bilateral basis. Second, refugees continute to immigrate. In fact, the acceptance of refugees has become a major gate of entry by which gaps in the labour market are filled. Third, the acceptance of diaspora immigrants continues particulary in Germany, and creates serious conflicts among the locals and the newcomers.

These contradicting developments and lack of social policies are notably felt by migrants and ethnic minorities living in Europe and undermine their situation. Furthermore, Europe is confronted with growing xenophobia and racism as well as ethnic conflicts today. The dimensions of racist aggressive behaviour are reflected in the figures. In 1992, there were 2.584 aggressions of foreigners which resulted in the deaths of 17 persons in the Federal Republic of Germany. This was an increase of more than $65 \%$ as compared to the previous year. The major targets were homes of asylumseekers, but also included migrants settled on a given community and even handicapped persons. $70 \%$ of the perpetrators were under 20 years of age. In the first seven months of 1993, a total of 1.223 aggressions against forcigners were registered in Germany. $43 \%$ of the perpetrators were students, $31 \%$ of them were skilled workers, $1 \%$ unskilled workers and $19 \%$ were unemployed. $14 \%$ of them were affiliated with a right extreme group or were known to have a right extreme, violent past. 
Not only Germany, but other European countries have also registered increasing figures of open animosity against foreigners, particulary Asians, blacks and Muslims in the last couple of years. Sweden, the Netherlands, France and Belgium are among these countries.

When we analyse the situation in Germany, we are surprised by the fact that the increase in xenophobia was not taken seriously by the responsible authorities until 1992. Only after open attacks were carried out against foreigners first in Hoyerswerda, then against asylum-seekers in Rostock, followed by the arson attacks on houses inhabited by Turks in Mölln and Solingen in 1992 and 1993, did the authorities realize that the extreme right danger was underestimated.

However, looking into the matter closer, the roots of xenophobia and racism can be traced back to the early 1980s. The process started then, but was visible oly in the field of social science. It was visible through texts which were circulated with regard to Turks. In these texts, Turks were often shown ridiculously different in their food tastes and dressing. To a lesser extent, in some texts, Turks were run over or stabbled in the back, incinerated with technological efficiency, boiled in hot water. The jokes were actually an expression of the widely shared emotions and values of the German society about Turks. They also revealed decp-seated fears and expressions of aggression and predicted eventual outbreaks in the form of destructive action.

Instead of discussing openly the issue of immigration and integration of foreigners in the Federal Republic of Germany, the German government adopted a more restricted policy towards foreigners by introducing legislation for limitation of immigration and an amendment of the Constitution of the Federal Republic of Germany with regard to the right of asylum. Unfortunately, no short or long term policies were developed, which would deal with the concepts of multi-ethnic coexistence and multicultural socicty.

What are the motives for racist behaviour in our societics? What do we see in common in those who come together with hatred for others? As Václav Havel puts it, a person who hates longs for self-confirmation. He is unhappy, "because whatever he does to achieve recognition by others and to destroy those he thinks are responsible for his lack of recognition, he can never attain the success he longs for". ${ }^{1}$ Looking at group hatred, - be it religious, idcological, social, national or any other kind - it is a kind of funnel in the words of Václav Havel, which draws into itself cveryone disposed towards individual hatred. For the person who hates, hatred is more

\footnotetext{
${ }^{1}$ Address by President Václav Havel in Oslo, Norway, August 28, 1990.
} 
important than its object. Object can be changed rapidly without changing anything essential in the relationship.

I believe it is not wrong to say that collective hatred has a special attraction especially for people who are susceptible to the suggestive influence of others. Collective hatred derives its magnetism from a number of factors. First of all, collective hatred eliminates loneliness, weakness, and the sense of being ignored while helping people in dealing with lack of recognition and of failure.

A second factor is the fact that collective hatred legalizes aggressiveness whereas individual aggressiveness is risky because the individual carries the responsibility alone. Potentially violent persons can dare to do more when they are hidden within a group and justify each other simply because there are more of them.

And finally, collective hatred provides those within the group a recognizable object of hatred. Manifestation of the general injustice of the world in a particular person is made easier if the offender is identifiable by the color of his skin, his name, his language or religion.

There are of course a couple of other factors which enable and failitate the birth of racist behaviour. For instance, our tendency to generalize is a good starting point for collective hatred. A group of people defined in a certain way - ethnically, for instance - deprives us of our individual responsibilities and make individuals become $a$ priori bad simply because of their origin. Furthermore, we can also say that racism finds a breeding ground in those environments where people live in genuine need.

In the light of the points mentioned above, we can then ask ourselves the following questions: Do the ideological gaps in the world have an effect on racism? Is the resurgence of ethnonationalism in Eastern Europe and in the Balkans a consequence of the spiritual and mental black hole left after the dissolution of the communist system? Does the formation of a European Union - a European fortress for many - influence racist tendencies in our countries? Do we go through a moral crisis in the West in which tolerance becomes synonymous with indifference or do we have a crisis in European humanist values? Is it an economic crisis which excludes an increasing part of Europe's population? These are the questions we must seck an answer to in our discussions.

There are obvious limitations on the mechanisms of formal democracy in combating xenophobia, aggressive nationalism, recism and other manifestations of the extreme right. But there are, nevertheless, many legal, social and economic actions we can take to combat racism and xenophobia. 
Recognition of dual nationality and easing naturalization, recognition of the right to vote and stand in local elections, equal opportunities' policies, enactment of anti-discrimination laws and finally a stronger control over the extreme right-wing organizations are a few, but very important ways of improving the situation of migrants in our societies and combating racism.

I would also like to touch upon an important point here: the role of education in combating xenophobia and racism. The existing educational system in most European countries are not equipped to train the coming generations for international mobility and cultural diversity. The socialization process carried out by families, schools and peers needs a brand new reconceptualization, such as reviewing textbooks with a view to strengthen teaching of anti-racist values. Teaching of foreign cultures and history, for instance, would lead young people to develop a sense of respect and understanding for the migrant populations and minorities living in their countries.

\section{Islam in Germany:}

Within this context, Islam has a significant meaning. Since the immigration of Muslim workers within the framework of the recruitment agreements, Islam became the second most spread religion after Christianity and produced the second largest religious community in Europe.

Looking at Germany for instance, presently there are 2.2 million Muslims living in this country. A large part of them, about $80 \%$, are from Turkey. The rest are from Iran, Morocco, Lebanon, Tunisia and Pakistan. A small, but an increasing number of Muslims in Germany are of German origin-about 50.000 .

Islam is an important element in the life style of many Turks. It goes beyond belief and becomes an expression of identity as well as a way of protection, especially for those who are disillusioned by their migration experience.

At this stage, the policies of the receiving countries concerning Islam and their Muslim populations are of great significance in determining developments among Muslims in Europe. So far, questions such as religion lessons in school for the Muslim children and permission for building mosques have been generally approached with skepticism by the indigenous populations. As a result of an obvious deficit in fulfilling religious needs of the migrants, privately organized religious teaching in the form of Koran courses has attracted great interest. However, such a development may become dangerous due to the extreme radical nature of such organizations. This factor should be taken into consideration when developing policies in education and culture. 
Religious needs of the Turkish population, coupled with the indifferent attitude of the German authorities towards these needs - referring to freedom of religion - have also paved the way for the establishment and development of Turkish-Islamic organizations in the Federal Republic of Germany. These organizations presently enjoy the greatest support among all Turkish organizations in Europe. This fact alone indicates that in order to achieve a peaceful coexistence of different cultures and commmunities in Europe, it seems necessary to establish a dialogue with Islam and the foreign cultures.

\section{Political Participation and Dual Citizenship:}

The present immigration policies in the European countries are founded on the principle of equal obligations, i.e., full respect by migrant workers for legislation and other regulatory provisions on the same term as nationals. However, their integration is not based on the principle of equal rights and equal opportunities. Although migrants are required to pay taxes, obey the law and although their lives are as affected by government decisionmaking as any other resident, they have no or very little say in the decisionmaking process. This is especially true for countries such as Germany which have not recognized the right to vote and stand in local elections for foreigners.

If a substantial number of permanent residents cannot vote, the legitimacy of political decision-making process is impaired. It must be noted that the existence of such disenfranchised groups in significant numbers throughout Europe undermines democracy.

Political participations, such as by means of the right to vote, would be an effective means for the integration of foreigners. It would also ensue an engagement among the political parties on the matter of foreigners. At the same time, it could also result in an effective and well-designed integration policy. The assurance of local voting rights in countries like Sweden, the Netherlands, Denmark and Ireland and the positive experiences of these countries should be a model for countries such as Germany who have not yet introduced such a right.

At the same time, the political interests of immigrants, which are more home-country oriented, could be directed, with the introduction of the local voting right, towards the events occurring in the country they live in.

According to the results of a survey conducted by the Center for Studies on Turkey among four nationalities (namely, the Turks, Greeks, Italians and former Yugoslavians) in the Federal Republic of Germany in September 1994, the right to vote and stand in local elections are very 
important for $46 \%$ of the foreigners who have been interviewed in the survey. The total number of interviewees was 1412 in the survey. 601 of them were Turkish, 212 were Greeks, 239 were Italians and 360 of them were coming from former Yugoslavia.

Analysing Turks as a separate group, the results of the survey show that for $62 \%$ of the Turks, the right to participate in local elections in Germany is very importanat, and for $21 \%$ of them it is important. So totally, $83 \%$ of the Turks consider this right as being important.

Table 3: Which political party would you vote for in there were federal parliament elections next Sunday?

\begin{tabular}{|l|c|}
\multicolumn{1}{c}{ Political Partics } & Turks \\
\hline Social Democrat Party (SPD) & $49 \%$ \\
\hline Grünen/Bündnis 90 & $11 \%$ \\
\hline Free Democrats Party (FDP) & $19 \%$ \\
\hline Christian Democrats Party (CDU) & $6 \%$ \\
\hline Democratic Socialist Party (PSD) & $1 \%$ \\
\hline None & $9 \%$ \\
\hline No answer & $15 \%$ \\
\hline
\end{tabular}

Source: Zentrum für Türkeistudien.

As can be seen from the table, SPD is the most preferred party among the German political parties for Turks. The fact that SPD is the traditional workers' party and that it pursues a more friendly policy towards migrant workers and foreigners than the other German parties leads to the above results. Yet, it must also be mentioned that the SPD has lost its potential to some extent in the last ten years. According to a survey done by the Kommunalverband Ruhrgebiet in 1983, the SPD could get $88 \%$ of the total votes in some neighbourhoods where Turks were denscly populated. Another survey made by the Center for Studies on Turkey in 1986 indicated that the SPD would get $63 \%$ of all the Turkish votes provided that the right to vote in local elections was recognized.

Compared to Greeks, Italians and former Yugoslavians, Turks show a greater interest in this kind of political participation. It must here be 
mentioned that Greeks and Italians do already have the right to participate in local elections according to the decisions taken at the Maastricht Treaty.

Dual citizenship is another means of promoting the integration of foreigners in our societies. This is especially true for countries again like Germany and Luxembourg. For instance, numerous Turks who could apply for German citizenship here do not ultimately do so, as this would require giving up their Turkish citizenship. For some Turks, this would also mean the loss of inheritance claims. Yet, renunciation of the Turkish citizenship often means more than the loss of certain rights in the homeland; it is also felt as the renunciation of one's own cultural identity and a complete detachment from one's homeland.

According to the results of the survey mentioned above, which is conducted by the Center for Studies on Turkey, $55 \%$ of the interviewees have stated that they would be ready to take up German citizenship provided they could keep their present citizenship. While two-thirds of the Turks and the former Yugoslavians say "yes" to dual citizenship, less than one-third of the Grecks are interested in dual citizenship.

Taking into consideration the populations of Turks and former Yugoslavians, 1.92 million and 920.000 respectively, these results show that approximately 1.6 million foreigners would take up German citizenship with the recognition of dual citizenship.

Table 4: Would you take up German citizenship if you could keep your present citizenship?

\begin{tabular}{|l|c|c|c|c|c|}
\hline & Total & Turks & Grecks & $\begin{array}{c}\text { Former } \\
\text { Yugoslavians }\end{array}$ & Italians \\
\hline Yes & $55 \%$ & $62 \%$ & $29 \%$ & $69 \%$ & $47 \%$ \\
\hline No & $21 \%$ & $14 \%$ & $34 \%$ & $24 \%$ & $23 \%$ \\
\hline Do not know & $17 \%$ & $14 \%$ & $37 \%$ & $5 \%$ & $14 \%$ \\
\hline No answer & $8 \%$ & $10 \%$ & $0 \%$ & $1 \%$ & $16 \%$ \\
\hline
\end{tabular}

Source : Zentrum für Türkeistudien.

Especially following the recent rise in the incidences of racist attacks in the Federal Republic of Germany, the prospect of legalizing dual citizenship appeared on the agenda among the general public and politicians. Although dual citizenship has been considered as a promising means of counteracting racism, such that Turks and other foreigners could have the 
same recourse to German law and courts, the discussion in the German Parliament on dual citizenship met the barriers of the CDU.

Another means to promote the integration of foreigners in Germany and other European countries would be to legalize their employment in public services. Voting is only one means of expressing political preferences. Additional means of political participation are essential if immigrants are to exert influence over public policy. Public services should recruit staff who are themselves of migrant origin and apply equal opportunities' policies in their personnel management. Public service jobs should be open to nonnationals as far as possible. This would promote their acceptance by the nationals.

Finally, one further legal means of countering problems foreigners face would be to enact an anti-discrimination law, such as those found in England and in Italy. This would also serve as a legally more enforcable counter-measure against racist attacks. 